\title{
KEARIFAN LOKAL DALAM PENGUSAHAAN USAHATANI PADI SAWAH DI DESA TALANG KEMULUN KECAMATAN DANAU KERINCI KABUPATEN KERINCI
}

\author{
The Local Wisdom In Cultivation Of Paddy Farming In The Talang Kemulun Village Kerinci Lake \\ District Kerinci Regency
}

\author{
Sesmi Rozaita ${ }^{1)}$, Rosyani ${ }^{2)}$ dan Fendria Sativa ${ }^{2)}$ \\ 1) Alumni Program Studi Agribisnis Fakultas Pertanian Universitas Jambi. \\ 2) Staf Pengajar Jurusan Agribisnis Fakultas Pertanian Universitas Jambi. \\ Email : Seza.Mr.JJ@Gmail.com
}

\begin{abstract}
ABSTRAK
Penelitian ini bertujuan untuk mengetahui penerapan kearifan lokal usahatani padi sawah dan hubungan kearifan lokal dan pengaruhnya dalam pengusahaan usahatani padi sawah di desa Talang Kemulun Kecamatan Danau Kerinci Kabupaten Kerinci. Pemilihan lokasi secara purposive (sengaja) dengan pertimbangan masih mengusahakan usahatani padi sawah dan memiliki kearifan lokal yang tinggi misalnya kenduri tuai (syukuran setelah panen), turun kesawah secara serentak dan pembagian gilir sawah secara kalebu. Metode penarikan sampel menggunakan metode random sampling dengan jumlah sampel 50 responden, hal ini petani sampel dikategorikan homogen. Data dari responden dianalisis menggunakan metode seperti yang dikemukan oleh Miles dan Huberman (2009) dengan langkah-langkah : 1). Reduksi data, 2). Penyajian data, 3). Penarikan kesimpulan/verivikasi. Hasil pembahasan penelitian diketahui bahwa Penerapan kearifan lokal dapat berupa sebagai pola pengetahuan dalam usahatani, bermanfaat untuk menghindarkan lahan pertanian dari degradasi sumberdaya alam dan dapat memberikan solusi dalam penghematan pengeluaran petani dalam perawatan seperti proses penanaman, pemupukan, pengairan, pengendalian gulma dan panen. Dan kearifan lokal yang mengacu kepada budaya lokal dalam pengusahaan usahatani, dengan memperhatikan pertimbangan bahwa secara ekonomis sangat menguntungkan, secara ekologis tidak mencemari lingkungan pertanian dalam jangka panjang dan secara sosial dapat diterima oleh seluruh masyarakat. Bentuk kearifan lokal yang ada di daerah penelitian adalah gotong royong/beselang, gilir ganti lahan, dan kenduri tuai (syukuran setelah panen).

Kata Kunci : Kearifan Lokal, Pengusahaan, Usahatani Padi Sawah.
\end{abstract}

\section{ABSTRACT}

This research aims to determine the application of local knowledge and relationships paddy rice farming local knowledge and influence in the business of paddy faring in the Talang Kemulun village Lake Kerinci District Kerinci Regency. The choice of location purposively (intentionally) with consideration still seeking paddy farming and have local knowledge of high festivity eg harvest (thanksgiving after the harvest), go down simultaneously and the distribution of paddy rice cultivation in kalebu. Sampling method using a random sampling method with a sample size of 50 respondents, it is categorized as a homogeneous sample farmers. Data from the respondents were analyzed using a method like the one raised by Miles and Huberman (2009) with the following steps: 1). Data reduction, 2). Presentation of data, 3). Conclusion / verification. The results of the discussion of the research note that the adoption of local wisdom can be as patterns in the farming knowledge, useful to prevent agricultural land from degradation of natural resources and can deliver solutions in expenditure savings of farmers in care such as planting, fertilizing, watering, weed control and harvesting. And local knowledge refers to the local culture in the business of farming, by taking into consideration that it is economically very profitable, ecologically farming does not pollute the environment in the long term and socially acceptable by the entire community. Forms of local wisdom in the area of research is of mutual cooperation / beselang, replace the shift of land, and the feast harvest (thanksgiving after the harvest).

Keywords: Local Wisdom, Cultivation, Paddy Farming 


\section{PENDAHULUAN}

Kedudukan subsektor tanaman pangan khususnya tanaman padi, dalam sektor pertanian masih sangat menonjol karena beras merupakan makanan pokok bangsa Indonesia. Kebutuhan beras dari tahun ke tahun harus meningkat seiring dengan peningkatan jumlah penduduk, sementara lahan pertanian semakin sempit dikarenakan banyaknya lahan yang beralih fungsi sehingga menimbulkan masalah baru dalam peningkatan produksi beras.

Luas Lahan Provinsi Jambi yang produktif untuk usahatani padi sawah adalah seluas 127.931 Ha. Jika dilihat tingkat produktivitas padi sawah perkabupaten, pencapaian produktivitas padi untuk Kabupaten kerinci tinggi bila dibandingkan dengan kabupaten lain, (Badan Pusat Statistik Provinsi Jambi 2012). Kabupaten Kerinci mempunyai produksi dan produktifitas padi tertinggi dalam Provinsi Jambi. Hal ini disebabkan petani padi sawah sudah banyak yang mengusahakan padi sawah secara modern (maju) dan semi modern, dengan perkembangan zaman, usahatani padi berkembang dari usahatani tradisional sampai pada usahatani maju (modern). Namun, masih ada desa yang masih mengusahakan usahatani padi sawah secara tradisional. Pertanian tradisional di desa dalam Kecamatan Danau Kerinci masih mempertahankan kearifan lokal. Didalam kehidupan masyarakat terdapat nilai-nilai sosial yang membentuk kearifan lokal dan telah menjadi bagian dari kehidupan sehari-hari.

Menurut Sonny Keraf (2002) dalam Suhartini (2009) menyatakan bahwa kearifan lokal/tradisional adalah semua bentuk pengetahuan, keyakinan, pemahaman, dan wawasan serta adat kebiasaan (budaya) atau etika yang menuntun perilaku manusia dalam kehidupan komunitas ekologis. Kearifan Lokal di desa dalam usahatani padi sawah dimana petani menerima dan percaya keadaan tanah yang subur, ketersediaan air, serangan hama dapat diatasi secara bersama dan dengan kemampuan potensi alam yang tersedia tenaga kerja secara beselang / gotong royong. Seluruh kearifan lokal ini dihayati, dipraktekkan, diajarkan, diwariskan dari satu genrasi ke generasi. Begitu juga Desa Talang Kemulun dalam usahatani padi sawahnya diusahakan secara mengikuti kebiasankebiasaan lama (tradisional) dan kegiatan menanam padi masih dilakukan satu kali dalam setahun dan proses penanaman padi dilakukan dengan serempak guna mengurangi kerugian akibat serangan hama, dalam pengolahan usahatani mereka selalu bergotong royong. Menurut Sakjoyo dan Pujiwati Sakjoyo (dalam Timumun, 2014) mengemukakan gotong royong merupakan adat istiadat tolong menolong antara warga dalam berbagai macam lapangan aktivitas sosial, baik berdasarkan hubungan tetangga kekerabatan yang berdasarkan efisien yang sifatnya praktis dan ada pula aktifitas kerja sama yang lain.

Menurut Koenjaraningrat (dalam Timumun, 2014 ) mengemukakan gotong royong merupakan suatu konsep yang erat sangkut pautnya dengan kehidupan masyarakat sebagai petani pada masyarakat agraris. Kerja sama lain yang dimaksud adalah kesepakatan yang dibuat oleh petani dalam pembayaran upah untuk pekerja, selain menggunakan uang juga dapat dibayar menggunakan tenaga kerja yang mereka sebut dengan berselang. Sebagian besar petani hasil panen yang sebelumnya digunakan sebagai bibit untuk musim tanam berikutnya, tenaga kerja yang berperan adalah wanita (ibu-ibu), terutama dalam proses penanaman, pemberantasan gulma (penyiangan) dan dalam proses pemanenan menggunakan sabit. Setelah panen masyarakat di Desa Talang Kemulun mengadakan kenduri (syukuran) yang disebut dengan kenduri sudah "tuai" (panen), ini dilakukan dengan maksud untuk menunjukkan bukti syukur masyarakat terhadap hasil pertanian padi sawah yang diperolehnya dan juga untuk menjalin silaturahmi. Kenduri dalam Kamus Besar Bahasa Indonesia (KBBI) berarti perjamuan makan untuk memperingati peristiwa, meminta berkah,dan sebagainya. Kenduri atau yang lebih dikenal dengan sebuatan selamatan telah ada sejak dahulu sebelum 
masuknya agama ke Nusantara. Dalam praktikya, kenduri merupakan sebuah acara berkumpul dengan tujuan meminta kelancaran atas segala sesuatu yang dihajatkan dari sang penyelenggara yang mengundang orang-orang sekitar untuk datang yang dipimpin oleh orang yang dituakan atau orang yang memiliki keahlian dibidang tersebut. Di desa Talang Kemulun acara ini biasanya diadakan di musholla atau di mesjid dengan mengundang kyai atau ustad/ustadzah sebagai penceramah dan pemimpin do'a.

Desa Talang Kemulun tidak bisa melakukan perluasan lahan usahatani padi sawah dikarenakan lokasi desa ini dikelilingi perbukitan (perkebunan rakyat) dan juga hutan TNKS (Taman Nasional Kerinci Seblat). Sebagian besar lahan sawah yang ada di desa Talang Kemulun merupakan milik bersama (common property), dimana dalam sistem gilir ganti sawahnya telah diatur berdasarkan kesepakatan antar keluarga (Kalbu), yang mendapat giliran punya hak untuk memanfaatkan lahan, tetapi tidak diperkenankan untuk memiliki atau menjual lahan sawah tersebut. Gillir ganti lahan sawah yang terdapat dalam masyarakat kerinci khususnya masyarakat Talang Kemulun pada prinsipnya berkaitan erat dengan sistem kewarisan. Menurut Djakfar (1993), gilir ganti lahan sawah merupakan salah satu bentuk dari cara pembagian warisan yang terjadi dalam masyarakat kerinci, sistem kewarisan masyarakat kerinci kedudukan ahli waris perempuan lebih diperhatikan demikian juga pada harta peninggalan. Menurut Idris (2011), sistem gilir ganti lahan sawah adalah cara pemakaian harta warisan yang berupa sawah yang ditinggalkan oleh sipewaris, dan oleh ahli waris tidak dibagikan diantara sesama mereka, namun hanya digunakan, dipakai, atau dikelola untuk memperoleh hasil dari objek waris tersebut, secara bergantian dianta para ahli waris yang berhak atas tanah tersebut, melalui suatu ketentuan hukum adat. Hal ini, menyebabkan sebagian kepala keluarga petani padi sawah setempat memiliki lahan sawah tiap tahun berbeda-beda.

Penelitian ini bertujuan untuk mengetahui penerapan kearifan lokal dan pengaruhnya dalam pengusahaan usahatani padi sawah di desa Talang Kemulun Kecamatan Danau Kerinci Kabupaten Kerinci

\section{METODE PENELITIAN}

Ruang lingkup difokuskan untuk mengetahui penerapan keaifan lokal dan hubungan kearifan lokal terhadap pengelolaan ushatani padi sawah. Penelitian ini dilaksanakan di Desa Talang Kemulun Kecamatan Danau Kerinci Kabupaten Kerinci. Pemilihan lokasi ini secara sengaja (purposive), dengan pertimbangan lokasi tersebut melakukan kearifan lokal seperti tradisi dalam pengelolaan usahatani padi sawah yakni kegiatan gotong royong/berselang dalam pengelolaaan usahatani padi sawah, adanya system gilir ganti lahan sawah, tradisi acara syukuran setelah panen (kenduri tuai), turun kesawah secara serentak, serta tidak bisa melakukan perluasan lahan sawah lagi karena dikelilingi perbukitan dan perkebunan rakyat.

Petani yang dijadikan objek adalah petani yang mengelola usahatani padi sawah serta bertempat tinggal di desa secara turun-temurun. Penelitan ini dilaksanakan pada tanggal 22 desember 2014 sampai tanggal 22 Januari 2015. Data yang digunakan merupakan Data primer yaitu data yang dikumpulkan secara langsung dari responden yang dalam hal ini adalah petani padi sawah berdasarkan dari pertanyaan-pertanyaan dengan kuisioner yang telah disiapkan. Dan data sekunder dalam penelitian adalah data yang diperoleh dari Badan Pusat Statistik (BPS), serta Balai Penyuluh Pertanian Peternakan dan Kehutanan (BP3K) Danau Kerinci, serta data dari desa tempat penelitian. Penelitian ini merupakan penelitian kualitatif. Data/informasi yang diperoleh dijadikan bahan analisis merupakan data dan informasi utama dalam penelitian ini adalah 
responden. Responden dipilih secara sengaja (purpossive) atas pertimbangan keterwakilan aspek permasalahan yang diteliti (Sitorus dalam Muchlis, 2009). Responden dinilai mampu memberikan data/informasi sesuai dengan kebutuhan penelitian.

Penarikan sampel dilakukan dengan menggunakan cara acak sederhana (Simple Random Sampling) yakni tehnik penentuan sample dengan pertimbangan Petani yang mengusahakan usahatani padi sawah dan bertempat tinggal di desa secara turun-temurun dengan $50 \mathrm{KK}$ petani sampel, hal ini petani sampel dikategorikan homogen. Pengumpulan data dalam penelitian ini dilakukan dengan mengikuti pola yang dikemukakan oleh Miles dan Huberman (2009), yakni melalui : 1). Wawancara, 2). Observasi, 3). Studi dokumentasi. Dalam penelitian ini, peneliti menggunakan jenis wawancara dengan pedoman umum dimana peneliti dilengkapi panduan wawancara berupa pertanyaan-pertanyaan yang telah peneliti siapkan sebelumnya.

Metode pengumpulan data/informasi serta sumber data/informasi yang dibutuhkan dalam penelitian ini dapat dilihat pada Tabel 1 .

Tabel 1. Jenis, metode pengumpulan data, dan sumber informasi dalam penelitian.

\begin{tabular}{lllll}
\hline No & Jenis data atau informasi & $\begin{array}{l}\text { Metode } \\
\text { pengumpulan data }\end{array}$ & $\begin{array}{l}\text { Sumber } \\
\text { informasi }\end{array}$ & dan \\
\hline 1 & $\begin{array}{l}\text { Identitas petani sampel } \\
\text { Meliputi: Nama, umur, pendidikan, observasi } \\
\text { jumlah anggota keluarga, lama } \\
\text { berusahatani, dan luas lahan } \\
\text { usahatani. }\end{array}$ & $\begin{array}{l}\text { Responden, Kantor } \\
\text { Desa, dan Kantor } \\
\text { BP3K }\end{array}$ & \\
& $\begin{array}{l}\text { Penerapan kearifan lokal dalam Wawancara } \\
\text { pengusahaan usahatani padi sawah } \\
\text { meliputi : gotong royong, gilir ganti } \\
\text { lahan, syukuran setelah panen } \\
\text { (kenduri tuai). }\end{array}$ & Responden & \\
\hline
\end{tabular}

Data dari responden dianalisis menggunakan metode seperti yang dikemukan oleh Miles dan Huberman (2009) dengan langkah-langkah : 1). Reduksi data, 2). Penyajian data, 3). Penarikan kesimpulan/verivikasi. Reduksi data dalam penelitian ini akan dilakukan dalam bentuk proses pemilihan, pengeditan, pemusatan pada penyederhanaan, pengabstrakan dan transformasi data kasar yang muncul dari catatan di lapangan. Mereduksi data berarti merangkum, memilih hal-hal pokok, memfokus pada hal-hal yang penting, dengan demikian data yang direduksi akan memberikan gambaran yang lebih jelas (Sugiyono, 2009). Sehingga dapat disimpulkan bahwa reduksi data merupakan bahwa bentu analisis yang menajamkan, menggolongkan, mengarahkan, membuang yang tidak perlu dan mengorganisasikan data dengan cara sedemikian rupa sehingga data yang disuguhkan memiliki arti.

Penyajian data merupakan sekumpulan informasi tersusun yang kemungkinan adanya penarikan kesimpulan dan penarikan tindakan. Kesimpulan diversivikasi selama penelitian berlangsung dengan cara memikir ulang selama penulisan, tinjauan ulang pada catatan lapangan, peninjaukan kembali atau tukar pikiran antar teman sejawat untuk mengembangkan "kesepakatan intersubjektif", dan upaya-upaya yang luas untuk menempatkan salinan suatu temuan dalam sseperangkat data yang lain. Ketiga kegiatan analisis (reduksi data, penyajian data, dan penarikan kesimpulan) dilakukan merupakan proses siklus dan interaktif.

Selanjutnya data disunting, untuk menentukan kelengkapan data dan keabsahan data dicek ulang dengan membandingkan antar data. Seluruh data primer dan data sekunder ditelaah. Baru kemudian data dalam unit analisis sama dipisah lagi menurut konsep-konsep penting yang dijadikan dasar untuk menyederhanakan gambaran himpunan. Penelitian ditujukan untuk mengkaji kearifan lokal dalam pengusahaan lahan 
usahatani padi sawah di Desa Talang Kemulun Kecamatan Danau Kerinci Kabupaten Kerinci

\section{HASIL DAN PEMBAHASAN}

\section{Deskripsi Responden}

Identitas petani sampel dalam penelitian ini adalah identitas petani yang mengusahakan tanaman padi sawah. Penelitian dilakukan di desa Talang Kemulun. Adapun data-data yang dikumpulkan pada petani yang dijadikan sampel meliputi: nama, umur, jumlah anggota keluarga, luas Lahan, dan lama berusahatani. Menurut Hernanto (1996), pada umumnya petani yang berumur lebih muda dan sehat memiliki kemampuan fisik yang lebih cepat menerima hal-hal baru yang dianjurkan, hal ini disebabkan karena petani yang berusia muda lebih berani mengambil resiko. Usia seorang petani sangat menentukan produktivitas tanaman yang dihasilkan. Hernanto (1996), mengatakan bahwa usia produktif dalam usahatani adalah usia antara 15-50 tahun. Berdasarkan data responden menunjukkan bahwa keadaan umur petani responden sebagian besar $(32 \%)$ berada pada kelompok umur 42 - 48 tahun. Selanjutnya (22\%) berada pada kelompok umur 35 - 41 dan 49 - 55 tahun. Pada usahatani padi sawah di daerah penelitian sebagian besar merupakan kelompok umur produktif.

Tingkat pendidikan terbanyak adalah Tamat SD (48\%), sedangkan tingkat pendidikan terendah adalah SMA sebanyak (22\%), ini menunjukan bahwa rata-rata pendidikan petani di daerah penelitian masih rendah sehingga akan berpengaruh terhadap penyerapan informasi. Di daerah penelitian ini petani memperoleh pendidikan non-formal seperti pembentukan kelompok tani. Aktifnya peran pendidikan non-formal menyebabkan petani dapat menerima teknologi-teknologi baru yang diberikan pemerintah melalui Penyuluh Pertanian Lapangan (PPL). Jumlah keluarga petani terbanyak pada selang kelas 4 - 5 orang yaitu $36 \mathrm{KK}$ atau $72 \%$, sedangkan jumlah anggota keluarga paling sedikit 2 3 orang $14 \mathrm{KK}$ atau $28 \%$ Artinya jumlah anggota keluarga petani yang tersedia akan dicurahkan atau dikerahkan untuk kegiatan usahatani cukup tinggi, sehingga dapat menghasilkan pengelolaan usahatani padi sawah yang tinggi. Hernanto (1998), mengatakan bahwa besarnya anggota keluarga akan berpengaruh dalam kegiatan usahataninya, petani yang memiliki keluarga yang terbesar akan memakainya untuk kegiatan usahataninya, sehingga tidak memakai tenaga upahan. Besarnya jumlah anggota keluarga akan mempengaruhi sumber potensi bagi kegiatan usahataninya. Karena anggota keluarga merupakan salah satu sumber daya manusia yang berpotensi sebagai tenaga kerja dalam mengelola usahatani.

Pengalaman berusahatani padi sawah paling Lama di daerah penelitian berada pada kisaran 23-27 tahun sebanyak 4\%. Pada selang 8 - 12 tahun petani paling banyak yakni $32 \%$. Pengalaman berusahatani yang cukup lama maka, petani mempunyai pengalaman yang tinggi sehingga dapat mengelola usahataninya dengan baik serta akan berpengaruh positif terhadap adopsi inovasi teknologi. Pengalaman seseorang akan dapat dijadikan tolak ukur untuk pengembangan dimasa yang akan datang. Menurut Suratiyah (2011), kecakapan seseorang menentukan kinerja seseorang. Seseorang yang lebih cakap tentu saja prestasinya lebih tinggi di bandingkan dengan yang kurang cakap. kecakapan di tentukan oleh pendidikan, pengetahuan dan pengalaman. Jadi, semakin lama pengalaman dalam berusahatani maka semakin cakap petani tersebut karena petani dapat belajar dari pengalaman yang telah lalu untuk menuju yang lebih baik, karena pengalaman merupakan pendidikan non-formal yang sangat bermanfaat. Lahan merupakan salah satu faktor produksi dalam berusahatani. Semakin luas lahan yang diusahakan maka akan semakin tinggi tingkat produksi dan pendapatan perkesatuan luasnya (Ken Suratiah, 
2006). Desa Talang Kemulun memiliki luas lahan yang berbeda-beda. Luas lahan usahatani dihitung per burong (dimana 1 Ha sama dengan 33 burong dan 1 burong sama dengan 10 meter persegi). luas lahan yang diusahakan dalam usahatani padi sawah berkisaran $0,54-0,78$ ha. Luas lahan tertinggi berkisar $0,59-0,63$ ha sebanyak $32 \%$ dari total petani.

\section{Kearifan Lokal Dalam Pengusahaan Usahatani Padi Sawah}

Kearifan lokal atau kearifan lingkungan masyarakat sudah ada di dalam kehidupan masyarakat semenjak zaman dahulu hingga saat ini, Kearifan lokal dalam pertanian tidak hanya memikirkan hasil pangan semata, namun juga berkaitan dengan menjaga kesehatan lingkungan sekitar. kearifan lokal/tradisional adalah semua bentuk pengetahuan, keyakinan, pemahaman, dan wawasan serta adat kebiasaan (budaya) atau etika yang menuntun perilaku manusia dalam kehidupan komunitas ekologis. Seluruh kearifan tradisional ini dihayati, dipraktekkan, diajarkan, diwariskan dari satu generasi ke generasi selanjutnya yang sekaligus membentuk pola perilaku manusia maupun terhadap alam yang gaib.

Kearifan lingkungan atau kearifan lokal masyarakat sudah ada di dalam kehidupan masyarakat semenjak zaman dahulu hingga saat ini, kearifan lingkungan merupakan perilaku positif manusia dan berhubungan dengan alam dan lingkungan sekitarnya yang dapat bersumber dari nilai-nilai agama, adat istiadat, petuah nenek moyang atau budaya setempat Wietoler dalam Akbar (2006) yang terbangun secara alamiah dalam suatu komunitas masyarakat untuk beradaptasi dengan lingkungan di sekitar.

\section{a. Gotong Royong / Beselang}

Dalam berusahatani masyarakat bersama-sama atau bergotong royong secara bergilir membantu satu sama lain (baselang). Kearifan lokal baselang/ botong royong ini merupakan adat istiadat tolong menolong antara warga dalam berbagai macam lapangan aktivitas sosial, baik berdasarkan hubungan tetangga, kekerabatan dan ada pula aktifitas kerja sama yang lain.

Hasil penelitian menunjukkan bahwa kearifan lokal dalam kegiatan baselang/gotong royong masih diterapkan dan berpengaruh dalam pengusahaan usahatani padi sawah. Berikut hasil penuturan petani.

Mengutip dari beberapa petani responden, mengatakan bahwa :

“... baselang dalam basawah menguntungkan kamai petani, upah ngan nak di bayar ke uhang dapat kito tabung dan kito gunokan untuk ngan biaya ngan lain. Baselang ni kito bagile nulung kantai biaso nyuh dalam penanaman, penyiangan, kading jugo dalam panen. Hitungannyuh berapo hari atau berapo jam tergantung kesepakatan." (Saidina Ali, 37 Tahun)

“... kegiatan baselang atau gotong royong nih membantu kamai dalam banyak hal, selain upahnyo di ganti dengan tenago kerjo kito, kito jugo biso babagi pengalaman dengan ngan lain, biso tambah dekat dengan yang lain, intinyoh silaturrahmi lanca. Kalo adek nanyo setuju atau ideak nyuh ya kamai setuju lah, apo lagi kamai ngan dak punyo ni slain tenaga kerjo apo lagi ngan nak jadi pembayar untuk upah nyuh." (Ishak, 43 Tahun)

“.... setuju kamai dengan adonyo baselang dan menguntungkan go deak banyeak ngalua uang dek, cuma taon inih kamai ngolah lahan suhang lah, ngungeai ngungeai karnu lahannyuh iket tanggong nyan nak ngupoh uhang. Gotong royong ni jugo dak dalam ngolah lahan be, kami 
biasonyo bagotong royong jugo dalam mena irigasi, mersih-mersih parit supayo aliran aye untuk sawah lanca." (M. Fahmi, 59 tahun)

“.... selain baselang kamai kading nyewa klumpok tani biaso nyuh dalam penanaman ngan panen, selain cepat selsai upah nyuh bisia go manyi pake hasilnyo "padi" tergantung kesepakatan. Kaloh manyi dingan padoi biasonyuh 1 karung/5 kaleng per uhang." (Sumarlin, 40 Tahun)

Hasil wawancara dengan responden di daerah penelitian dapat disimpulkan bahwa kearifan lokal baselang/gotong royong merupakan suatu elemen yang tidak dapat dipisahkan dan harus ada dalam berusahatani padi sawah yang masih diterapkan dan dapat memberikan solusi dalam penghematan petani dalam perawatan seperti proses penanaman, pemupukan, pengairan, pengendalian gulma dan panen. Baselang/gotong royong dalam berusahatani sangat membantu petani terutama pada saat bercocok tanam padi sawah, mereka jarang sekali mengeluarkan uang untuk membayar upah mereka dapat membayarnya dengan tenaga kerjanya dan biasanya dihitung dalam berapa hari kerja atau berapa jam kerja tergantung kesepakatan. Hal ini sejalan dengan pendapat Timumun (2014) yang menyatakan bahwa gotong royong dalam masyarakat merupakan suatu sistem pengarahan tenaga kerja tambahan dari luar keluarga untuk mengisi kekurangan dalam rangka aktivitas produksi bercocok tanam.

\section{b. Sistem Gilir Ganti Lahan}

Sistem gilir ganti lahan yang dimaksud adalah giliran petani yang mengelola lahan sawah milik nenek moyang, bedasarkan hasil penelitan dalam satu kali musim tanam petani yang mendapat giliran dalam mengolah lahan maka dia berhak atas lahan tersebut, mau dikelola sendiri atau memberi kepada petani lain yang mengelolanya dengan kesepakatan antara dua belah pihak. Dan apabila petani yang tidak memiliki lahan untuk bertanam padi sawah sambil menunggu giliran lahan sawah maka petani akan mencari mata pencaharian lain seperti berkebun atau berladang untuk memenuhi kebutuhan keluarga atau menggarap lahan sawah milik orang lain dengan sitem bagi hasil. Memiliki lahan untuk berusahatani merupakan simbol status sosial didalam masyarakat. Berikut hasil wawancara penulis dengan responden tentang kearifan lokal sistem gilir ganti lahan dalam pengusahaan usahatani padi sawah.

Mengutip dari beberapa petani responden, mengatakan hahwa :

“...kalau kamai nanam padi lah lamo, kamai menna lahan

uhang tuo, hampir galo2 uhang situn. Kamai mboh nanam padoi ini karnu nyo cepat panen dan jugo uhang basawah semuo biso dikatokan simbol status sosial. Karno kamai 4 bersaudara jadi lahan sawuahnyo yo bagile dengan padin ngan lain namonyo jugo sawah samun, walaupun lahannyo deak luaeh tapi lumayanlah hasilnyo cukot untuk makan anak binoi, ideak kamai mli beheh.".(Abdul Gani, 45 tahun)

"...kalau adek nuek manan pendapat kamai tentang sawuah bagile ni ya menguntungkan la buat kamai, karno itu la lahan sawah ngan kamai ado nahuh dahi pado dag ado sawuah jadeilah. Kamai nanam padi sawah karnu penen nyuh cepat apo lagi disiko nih cuma 1 kali musim tanam, kaloh deak basawah anak binoi nak makan apo. Sawuah bagile inih hasilnya alhamdulillah cukot la untuk makan. Walaupun tiap taunnya babedo-bedo luas lahannyo". (Agusman, 66 tahun)

"...akau garap lahan milik uhang dek karno kamai uhang dak punyo, yang punyo lahan dag ado ugok siko jadi kamai ngan garap nyuh. Kading sawuah kakak kamai ngan menna ugo, dengan bagi hasil nyuh 2:1 maksudnyo jumlah hasil galo-galo di bagi 3, 1 untuk pemilik lahan dan dua untuk kamai penggarap. Hasil yang diperoleh lumayan untuk 
makan sehari hari namanya juga garap lahan orang”. (Kasmadi, 47 tahun)

“.. lahan sawah kamai nih warisan dahi uhang tuo, dahi pado dak ado uhang ngan ngolah ilok jugo kami ngan ngolah. Bagile be ngan padin yg laen ngolah nyuh namu nyuh sawoh warisan banyak la ngan punyo. Karna 1 kali musim tanam dalam setahun kadang hasilnyo dikit kadang lumayan kan tiap taon babedo-bedo luas lahannyo." (Muhrizal Ahmad, 37 tahun.

Berdasarkan keterangan di atas menunjukkan bahwa kearifan lokal gilir ganti lahan sawah masih di terapkan dan dinyatakan sebagai usaha untuk memperoleh pendapatan atas lahan, juga sebagai tanda ikatan kekeluargaan (kekerabatan) serta menjaga martabat keluarga Kearifan lokal gilir ganti lahan sawah berkaitan dengan sitem warisan, Dengan pembagian sawah secara garis keturunan ini dapat menjaga tanah pertanian terutama pada zaman sekarang dengan semakin maraknya pembangunan, dan juga menjaga ketahanan pangan keluarga, gilir ganti lahan masih di terapkan namun ada sebagian petani memberi giliran sawahnya untuk di garap olek keluarganya dengan maksud untuk membantu kebutuhan keluarga, jadi bisa dikatakan giir ganti lahan hanya status.

\section{c. Kenduri Tuai (Syukuran setelah Panen)}

Kearifan lokal yang ada di masyarakat desa talang kemulun selain gotong royong/beselang dan sistem gilir ganti lahan juga terdapat acara kenduri tuai (syukuran setelah panen) yang bertujuan untuk menunjukkan rasa syukur kepada Tuhan Yang Maha Esa atas hasil panen yang didapat penduduk dalam berusahatani padi sawah, selain itu acara ini juga bertujuan untuk meningkatkan ikatan silaturrahmi dengan sesama warga. Berikut hasil kutipan wawancara mengenai acara syukuran setelah panen "kenduri tuai" dari beberapa petani responden, mengatakan bahwa :

“... kenduri tuai agoi uhang melaksanakannyuh, biaso nyuh di mushalla/surau. Kamai la lahang gin acara tuh, cuma nyumbang nakkawo atau biasonyo lemang, nasi dan gulai untuk di bagi-bagikan kek uhang ngan hadir. Acara inih tentang kepercayaan kito kek tuhan, kito mengadakan acara inih untuk mengucapkan terimakasih kek Allah SWT atas hasil panen sawoah kitao. Menurut akau deak ngaruh dengan hasil panen taon ateh dok tergantung kito mengelola lahan aso akau." (Ilyas Ismail, 51 tahun)

“... Acara inihkan tentang kepercayaan kito, dak ado go sanksi bagi uhang ngan dak merayakannyuh. Setuju la, karnu kamai setiap taon ado be hadir kek acara kenduri nih, kito bisia nengo ceramah dari ustad, namboh pengetahuan dan jugo silaturrahmi lanca. Deak ngaruh dengan hasil panen taon ateh dok, inikan cuma syukuran biaso untuk mengucapkan terimakasih atas hasil panen kitao.” (Mat Jalil, 66 Tahun)

Hasil wawancara dengan petani responden di daerah penelitian dapat disimpulkan bahwa kearifan lokal kenduri tuai (syukuran setelah panen) merupakan kepercayaan petani terhadap Tuhan Yang Maha Esa dan biasanya diadakan dimesjid atau di mushalla. Acara Kenduri tuai sama seperti acara syukuran biasa mengundang penceramah kyai atau ustad/ustadzah untuk memimpin do'a. Masyarakat tidak merasa dirugikan dan tidak ada sanksi bagi siapa yang tidak hadir dalam acara ini malah sebaliknya mereka menganggap acara syukuran ini dapat mempererat tali silaturrahmi antar warga, tetangga dan kerabat. Acara kenduri tuai menciptakan semangat baru dalam jiwa masyarakat untuk menghadapi musim tanam yang baru. Menurut Raemon (2010), Berdasarkan hasil penelitiannya ditemukan adanya tiga fungsi dari ritual pasca panen yakni fungsi religius spiritual ( 
menghubungkan manusia dengan dzat yang maha kuasa yang dianggap mampu membantu manusia dalam menjalankan aktivitas bercocok tanam), fungsi sosial ( menjadi jembatan relasi soisal yang integratif baik antara warga itu sendiri) dan fungsi psikologis (memunculkan keyakinan baru bahwa mereka telah menjadi individu yang berjiwa bersih).

\section{KESIMPULAN}

Dari urain di atas berdasarkan hasil penelitian yang dilakukan di lapangan, maka dapat diambil kesimpulan : Penerapan kearifan lokal dapat berupa sebagai pola pengetahuan dalam usahatani, bermanfaat untuk menghindarkan lahan pertanian dari degradasi sumberdaya alam dan dapat memberikan solusi dalam penghematan pengeluaran petani dalam perawatan seperti proses penanaman, pemupukan, pengairan, pengendalian gulma dan panen.

Kearifan lokal yang mengacu kepada budaya lokal dalam pengusahaan usahatani, dengan memperhatikan pertimbangan bahwa secara ekonomis sangat menguntungkan, secara ekologis tidak mencemari lingkungan pertanian dalam jangka panjang dan secara sosial dapat diterima oleh seluruh masyarakat. Bentuk kearifan lokal yang ada di daerah penelitian adalah gotong royong/beselang, gilir ganti lahan, dan kenduri tuai (syukuran setelah panen).

\section{UCAPAN TERIMA KASIH}

Pada kesempatan ini penulis ingin menyampaikan terima kasih kepada Dekan dan ketua Program Studi Agribisnis Fakultas Pertanian Universitas Jambi yang telah memfasilitasi pelaksanaan penelitian ini. Selain itu ucapan terimakasih kepada kepala desa Talang Kemulun yang memfasilitasi pelaksanaan penelitian dilapangan.

\section{DAFTAR PUSTAKA}

Biro Pusat Statistik. 2010. Provinsi Jambi Dalam Angka 2012.

Djakfar, Idris. Hukum Waris Adat Masyarakat Kerinci. Fakultas Hukum Universitas Jambi, 1993.

Hernanto, Fadholi. 1998. Ilmu Usahatani. Penebar Swadaya. Jakarta.

$\mathrm{http} / /$ hermawaneneriadi.com/kewaspadaan-nasional-terhadap-sistem-pertanian-berbasiskearifan-lokal/

Idris, Isran. Pola Penguasaan Tanah Sawah Secara Sistem Gilir Ganti Pada Masyarakat Hukum Adat Kerinci. Jurnal Vol 4, No 5 (2011).

Reamon. 2010. Lulo Ngganda: Ritual Pasca Panen Pada Orang Tolaki :: Anailis Interpretatif Fungional Atas Ritual Lulo Ngganda Di Desa Benua Kecamatan Benua Kabupatek Konawe Selatan Provinsi Sulawesi Tenggara. Yogyakarta.

Siegel.1997, statistik non parametrik untuk ilmu - ilmu sosial. Gramedia. Jakarta

Soekanto, Soerjono. 2005. Sosiologi Suatu Pengantar. PT. Raja Grafindo Persada. Jakarta. 
Suhartini. 2009. Kajian Kearifan Lokal Masyarakat dalam Pengelolaan Sumber Daya Alam dan Lingkungan. Seminar Nasional Pendidikan dan Penerapan MIPA, Fakultas MIPA, Universitas Negri Yogyakarta. 16 mei 2009. diakses tanggal 15 mei 2003.

Suratiah,Ken. 2006. Ilmu Usahatani. Penerbit Suadaya. Jakarta

Timumun, Amirullah A. 2014. Perubahan Sosial Buaya Masyarakat Buol. http://eprints.ung.ac.id/id/eprint/2335 